\title{
STABLE ISOTOPES AND DEBRIS IN BASAL GLACIER ICE, SOUTH GEORGIA, SOUTHERN OCEAN
}

\author{
By David E. Sugden, \\ (Department of Geography, University of Edinburgh, Edinburgh EH8 9XP, Scotland)
}

Chalmers M. Clapperton,

(Department of Geography, University of Aberdeen, Old Aberdeen AB9 2UF, Scotland)

J. Campbell Gemmell,

(Christ Church College, University of Oxford, Oxford OX1 1DP, England)

and Peter G. Knight

(Department of Geography, University of Keele, Keele ST5 5BG, England)

\begin{abstract}
This paper combines a study of the rock debris and $6 \mathrm{D} / \delta^{18} \mathrm{O}$ isotopic characteristics of basal ice sequences in three representative glaciers in South Georgia and concludes that the debris and ice has been entrained mainly by basal freezing. The size distribution of the rock debris is typical of crushing and abrasion, and reflects transport at the ice-rock interface. The $\delta D / \delta^{18} \mathrm{O}$ relationships show that clear ice associated with the debris has accreted through freezing. The white bubbly glacier ice has $\delta \mathrm{D} / \delta^{18} \mathrm{O}$ relationships typical of precipitation which demonstrates an altitudinal effect between glaciers.
\end{abstract}

\section{INTRODUCTION}

The aim is to characterize the basal ice sequence exposed in the snouts of some glaciers in South Georgia and to establish its origin. More specifically, we combine a study of the entrained rock debris with the analysis of the $\delta \mathrm{D} / \delta^{18} \mathrm{O}$ characteristics of the ice in order to test the hypothesis that the basal ice sequence has accreted through freezing at the glacier bed. The results are of interest for two main reasons. First, detailed descriptions of rock debris in glaciers are relatively rare, especially in the sub-Antarctic, and this hinders the development of firmly constrained models of glacier sliding, erosion, and deposition. Secondly, co-isotopic analysis of basal glacier ice has not previously been explored in the sub-Antarctic and Antarctic domains.

The approach to the study was to select three representative glaciers in South Georgia. Representing large glaciers with a high altitudinal range is Nordenskjöld Glacier (Fig. 1), which is $12 \mathrm{~km}$ long and $3.5 \mathrm{~km}$ across at its calving snout in Cumberland East Bay. The glacier is nourished in seven cirques etched into the Allardyce Range which includes the highest mountain in South Georgia, Mount Paget $(2936 \mathrm{~m})$. A great deal of increment to the glacier surface comes from snow and ice avalanches from surrounding peaks. Lyell Glacier represents the population of medium-sized glaciers and extends $7.75 \mathrm{~km}$ to sea-level from an altitude of $1050 \mathrm{~m}$ (Fig. 2). The snout is $2.5 \mathrm{~km}$ across; $1 \mathrm{~km}$ terminates on land, the remainder is grounded in shallow water. Representing small, low-altitude glaciers is Hodges Glacier, a small cirque glacier approximately $1 \mathrm{~km}$ in length and $1 \mathrm{~km}$ across. Its upper limit is delimited by the crest of the cirque backwall at $550-600 \mathrm{~m}$, while its snout lies at $340 \mathrm{~m}$.

We examined basal ice sequences at the western side of

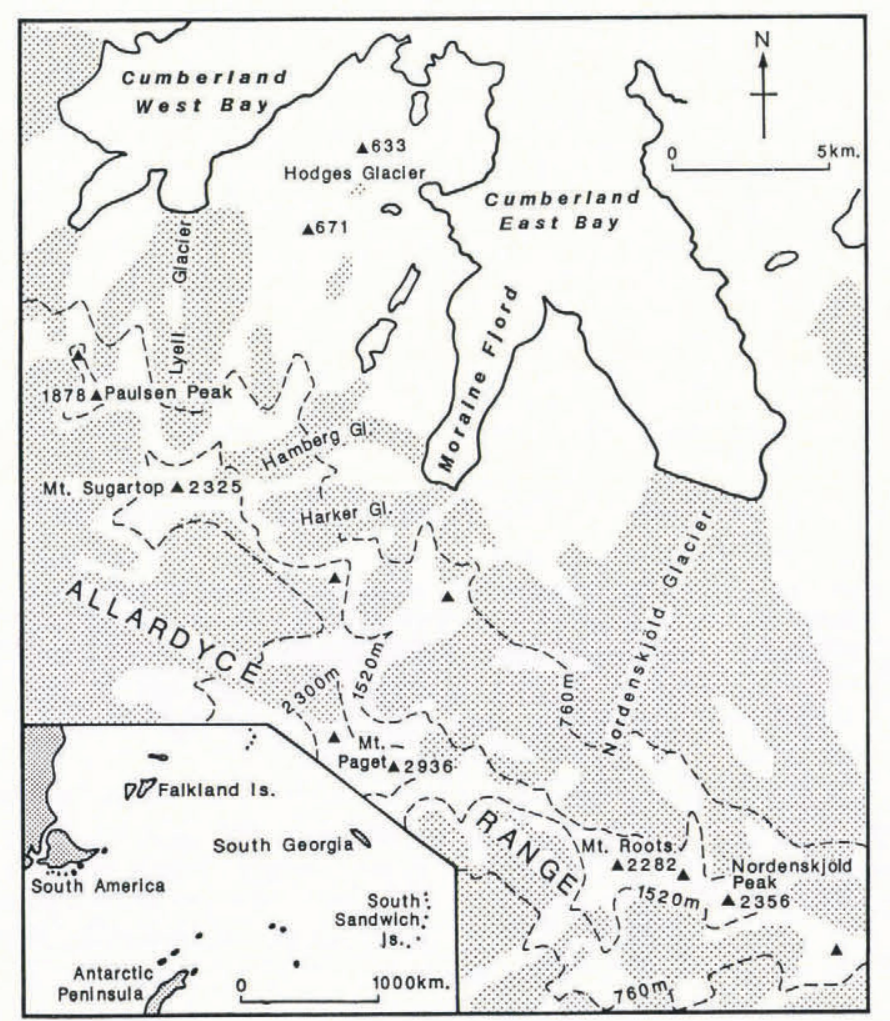

Fig. 1. The location of the three glaciers in South Georgia.

Nordenskjöld Glacier where it terminates on land, on both sides of Lyell Glacier, and at the snout of Hodges Glacier. Field work involved study of structural and stratigraphical relationships and large-calibre rock debris, and collection of debris-bearing ice samples $\left(\sim 50 \mathrm{~cm}^{3}\right)$ for laboratory analysis. The latter were weighed, melted in a sealed polythene bag, and immediately bottled for isotopic analysis. The bottles were sealed with wax until processed by $\mathrm{Dr} J$. Jouzel at the Centre d'Études Nucleaires de Saclay in France. The rock debris was dried, weighed, and analysed for its size and lithology in the laboratory. 


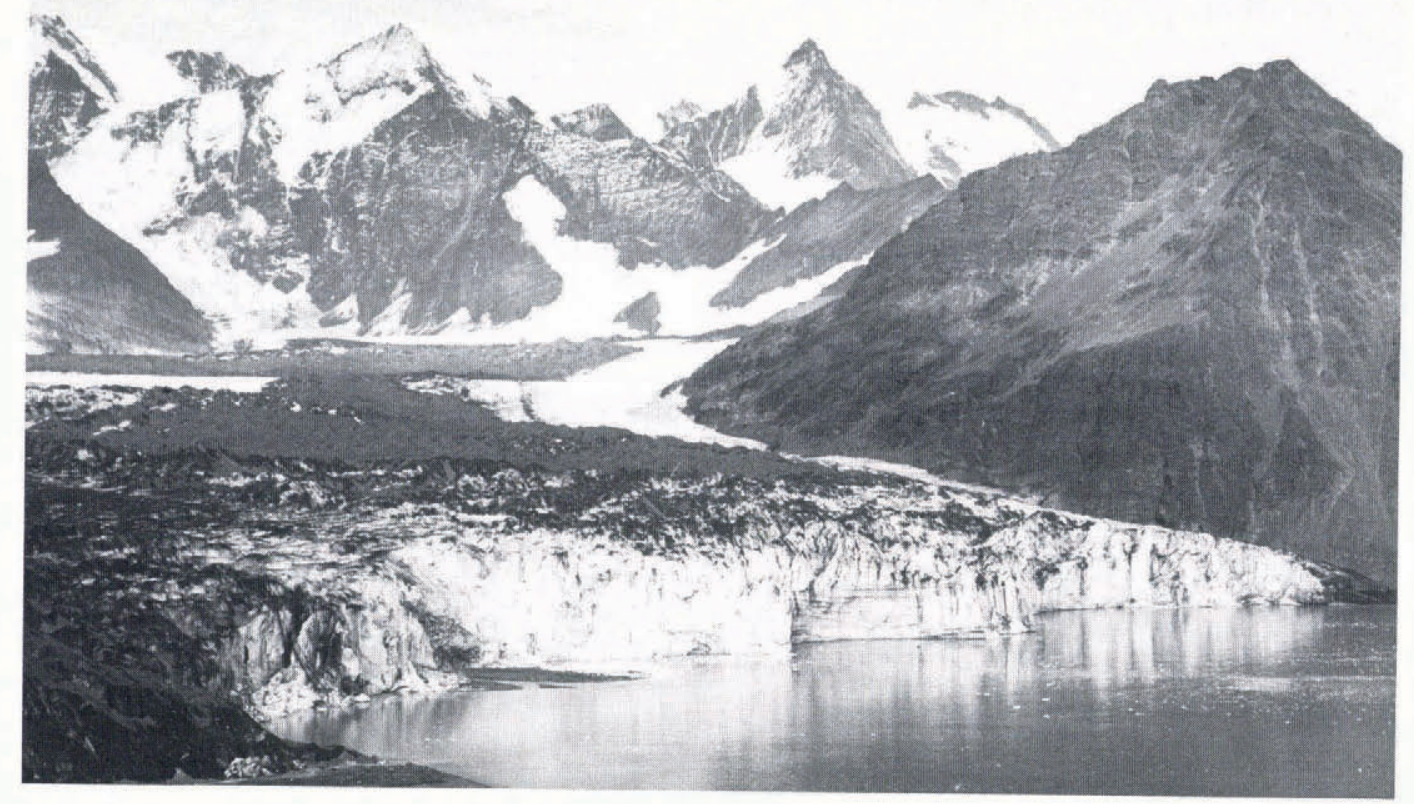

Fig. 2. Lyell Glacier looking south towards Paulsen Peak, March 1982, showing the widespread cover of
surface rock-fall material. surface rock-fall material. The basal ice was sampled at the land-bound parts of the snout to the
left (east) and the right (west) of the photograph.

\section{THE DEBRIS-BEARING SEQUENCES}

\section{Nordenskjöld Glacier}

The debris-bearing sequences exposed on a $26^{\circ}$ slope at the margin of Nordenskjöld Glacier consist of a series of debris bands separated by layers of ice with thin debris laminations (Figs 3 and 4); they dip up-glacier at angles of $36-56^{\circ}$. The debris bands are $4-15 \mathrm{~cm}$ thick and consist mainly of debris or of a cluster of discrete debris bands separated by millimetre-thick ice layers. The debris bands frequently contain sub-angular, abraded, and striated clasts $0.5-3 \mathrm{~cm}$ in size with occasional clasts up to $15 \mathrm{~cm}$. The ice between the debris bands is clear, contains few bubbles, and has crystals $1-2 \mathrm{~cm}$ in size. Fine debris occurs within crystals, along crystal boundaries, and in millimetre-thick laminations which can be followed laterally for several metres. At site $\mathrm{N} 11$, about 150 separate debris laminations separated by clear ice layers $1-2 \mathrm{~cm}$ thick occur in a $2 \mathrm{~m}$

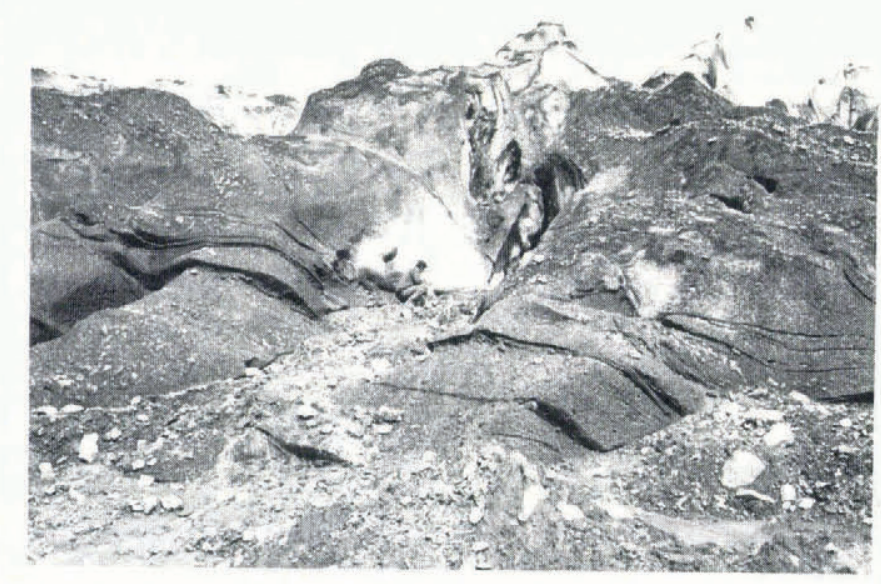

Fig. 3. The basal debris-bearing sequence at the western edge of the snout of Nordenskjöld Glacier, February 1985. The person is at the upper junction of the sequence. White bubbly ice above is covered with a veneer of surface rock-fall material.

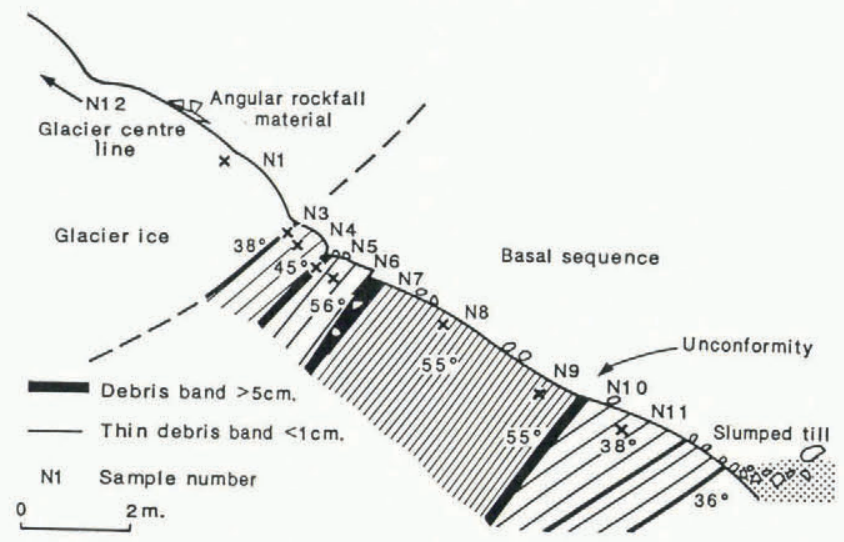

Fig. 4. Profile and sample sites, Nordenskjöld Glacier, February 1985. The debris contents (by weight) of the debris bands were: N3, 83.5\%; N5, 62.8\%; N7, $69.2 \%$; N10, $91.8 \%$. The debris contents of the intervening laminated ice layers were: $N 4,8.2 \% ; N 6,2.6 \% ; N 8,8.8 \%$; N9, $4.9 \%$.

thick band. Debris concentrations in the laminated ice vary between $2.6 \%$ and $8.8 \%$ by weight. Debris $<32 \mathrm{~mm}$ has a bimodal grain-size distribution with peaks at $16 \mathrm{~mm}$ and $63-125 \mu \mathrm{m}$; fine silt and clay $(<2 \mu \mathrm{m})$ is also present (Fig. 5). There are two exceptions: one example of laminated ice (N4) has no material coarser than $4 \mathrm{~mm}$, while one debris band (N5) has no fine material. The ice above the top debris layer is quite different. It is white and bubbly (crystal size 2-4 cm), and contains angular fragments of debris similar to that present as a rust-coloured veneer on the glacier surface.

\section{Lyell Glacier}

On Lyell Glacier, debris-bearing sequences 6-8 $\mathrm{m}$ thick are exposed in frontal ice cliffs of $30-50^{\circ}$ along the landbound eastern and western margins of the glacier (Fig. 2). The debris contains abraded and striated clasts, $82 \%$ of which are sub-rounded to rounded in shape. The debris-rich zones are separated by clearer ice (crystals $2-4 \mathrm{~cm}$ ) 
containing debris thinly distributed both within and between crystals. Twenty-eight samples were collected from the basal debris at the eastern margin of the glacier. Table I shows that the mean debris concentration in the debris-rich zone

\section{(a) NORDENSKJÖLD GLACIER}

$$
\begin{gathered}
\% \text { by } \\
\text { weight }
\end{gathered}
$$

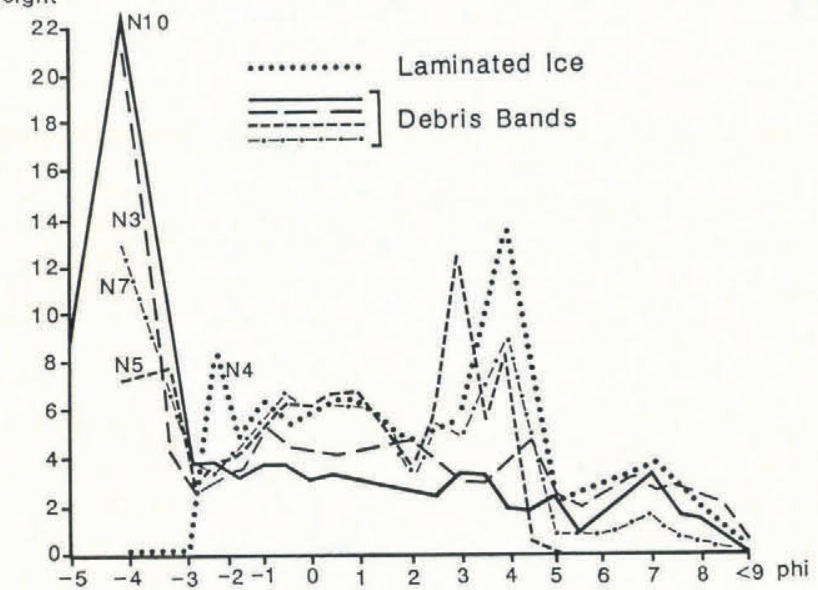

\section{(b) HODGES GLACIER}

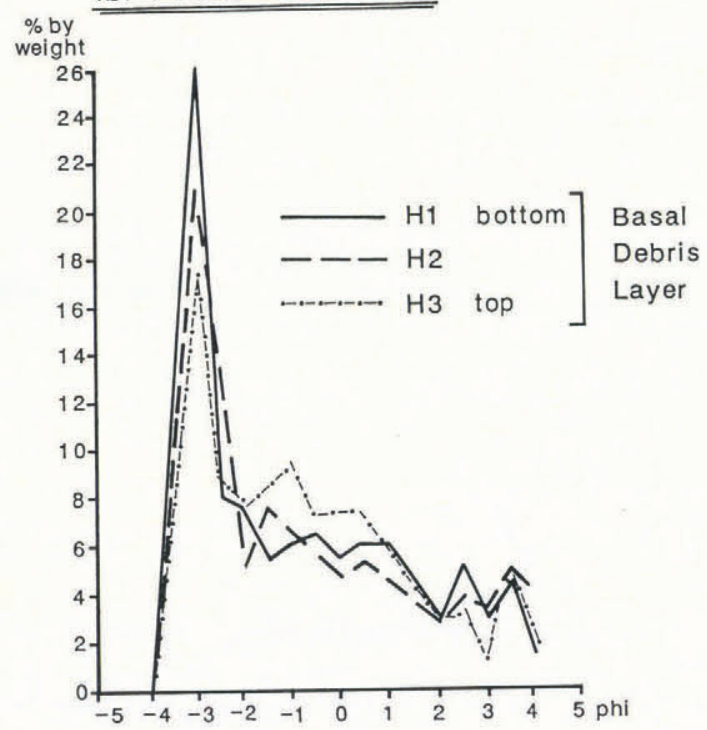

\section{(c) CRUSHED ROCK}

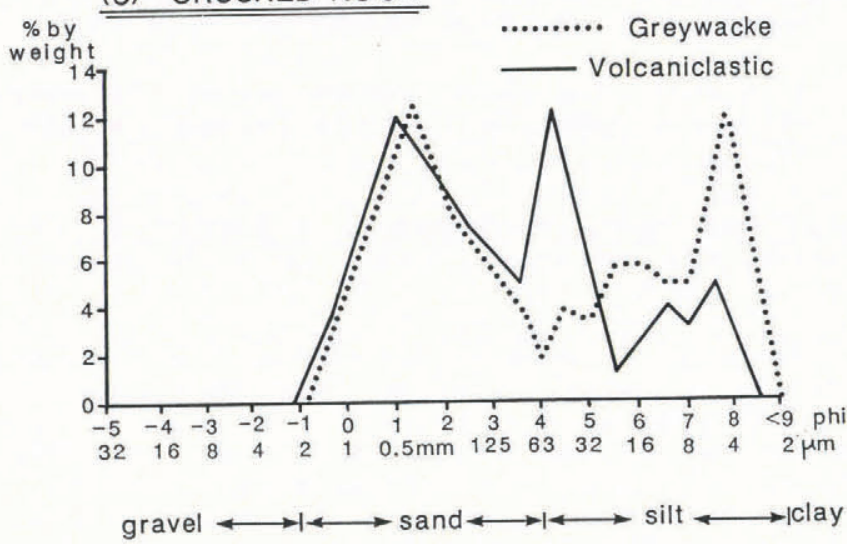

Fig. 5. Grain-size distribution of debris finer than $32-16 \mathrm{~mm}$ in (a) the Nordenskjöld Glacier profile, (b) Hodges Glacier, and (c) artificially crushed greywacke and volcaniclastic rocks. Samples of the latter were passed through spring-loaded rollers five times. The main features of the curves shown were achieved on the second pass. Thereafter there was a more gradual reduction of grain-size, especially the coarser fraction. (lower $2 \mathrm{~m}$ ) is $11 \%$ by weight and in the clearer ice $(2-5 \mathrm{~m}$ above the bed) it is $0.3 \%$ by weight. Overlying the basal sequence, and separated from it by a sharp discontinuity, is c. $50 \mathrm{~m}$ of banded white and blue ice; it consists of layers of white bubbly ice $30 \mathrm{~cm}$ thick and layers of blue ice $10 \mathrm{~cm}$ thick. This foliation is horizontal in mid-glacier and slopes up towards the margin. Within the ice there are low concentrations of rust-coloured angular rock debris (mean of ten samples being $0.057 \%$ by weight) similar to that on the glacier surface.

\section{Hodges Glacier}

The basal sequence in Hodges Glacier is only $1.3 \mathrm{~m}$ thick. It is visible in melt-water tunnels and in the lee of rock bumps beneath the $23^{\circ}$ slope of the ice margin. The sequence consists of discontinuous lenses of debris $1 \mathrm{~mm}$ to $1 \mathrm{~cm}$ in thickness separated by clear ice with sporadic or no bubbles; the debris lenses are of ten folded on a scale of $10 \mathrm{~cm}$. Abraded, striated, and angular clasts occur throughout the basal sequence. Debris concentrations are highest near the base $(46 \%$ by weight) and fall to $15 \%$ by weight $120 \mathrm{~cm}$ above the base (Fig. 6). The grain-size distribution of debris $<32 \mathrm{~mm}$ reveals a sharp peak at $8 \mathrm{~mm}$ with smaller peaks in the fine sand sizes (Fig. 5b). A sharp discontinuity separates the basal sequences from overlying ice that is bubbly and white with a crystal size of $c .1 \mathrm{~cm}$. The white bubbly ice is stratified; clear sedimentary layers c. $60 \mathrm{~cm}$ thick dip up-glacier and occur up to the firn line at c. $450 \mathrm{~m}$ (Fig. 7).

\section{ORIGIN OF THE DEBRIS}

There are two distinct populations of debris, the characteristics of which indicate their probable origin. The angular, rust-stained debris sporadically disseminated within

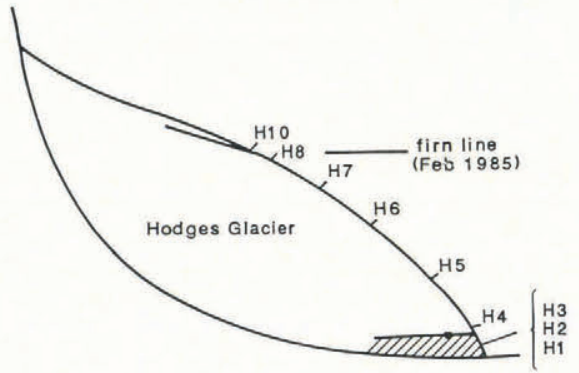

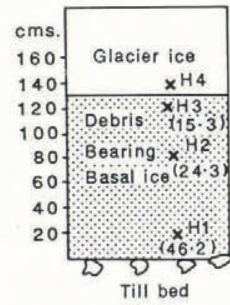

Fig. 6. The location of debris and isotopic samples on Hodges Glacier. (a) The glacier as a whole, and (b) details of the basal ice sequence near the snout. Concentration of debris is given in brackets.

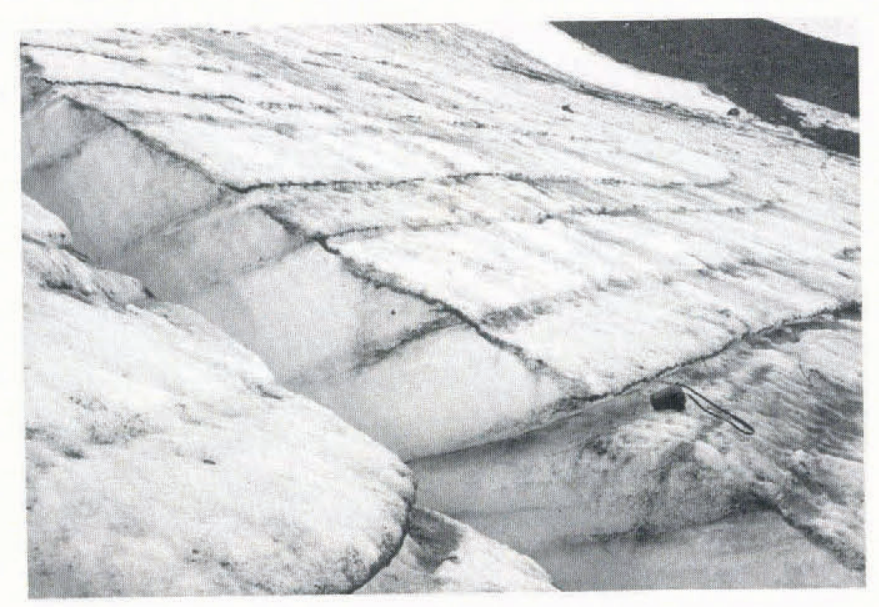

Fig. 7. Sedimentary layers exposed in a longitudinal crevasse on Hodges Glacier. February 1985. The camera on the ice measures $15 \mathrm{~cm} \times 15 \mathrm{~cm} \times 10 \mathrm{~cm}$. 
TABLE I. DEBRIS CONTENT OF BASAL ICE IN SOME SOUTH GEORGIA GLACIERS, GIVEN BY WEIGHT \% AND g PER LITRE OF WATER MELTED. ICE FACIES AFTER LAWSON (1979)

\begin{tabular}{|c|c|c|c|c|c|c|c|}
\hline \multirow[b]{2}{*}{ Glacier } & \multirow[b]{2}{*}{ Ice facies } & \multirow[b]{2}{*}{ Location } & \multirow[b]{2}{*}{$\begin{array}{c}\text { Number of } \\
\text { samples }\end{array}$} & \multirow[b]{2}{*}{$\begin{array}{l}\text { Mean } \\
\text { weight \% }\end{array}$} & \multicolumn{3}{|c|}{ Debris content } \\
\hline & & & & & $\begin{array}{c}\text { mean } \\
\mathrm{g}^{-1}\end{array}$ & $\min ^{-1}$ & $\begin{array}{l}\max \\
\mathrm{g} 1^{-1}\end{array}$ \\
\hline \multirow[t]{5}{*}{ Lyell } & Basal stratified & East margin & 13 & 11.3 & 154 & 1.4 & 530 \\
\hline & Basal stratified & West margin & 4 & 14.6 & 381 & 97 & 855 \\
\hline & Basal dispersed & East margin & 22 & 0.13 & 0.71 & 0.1 & 4.6 \\
\hline & Basal dispersed & West margin & 4 & 0.95 & 12 & 1.9 & 26.1 \\
\hline & Englacial diffused & $\begin{array}{l}\text { Overlying white } \\
\text { bubbly ice }\end{array}$ & 10 & 0.057 & 0.15 & 0.016 & 0.5 \\
\hline Hodges & Basal stratified & Mid snout & 3 & 28 & 453 & 180 & 857 \\
\hline \multirow[t]{3}{*}{ Nordenskjöld } & Basal stratified & & 8 & 41.5 & 2554 & 26 & 11150 \\
\hline & Basal stratified & Debris bands & 4 & 75 & 5043 & 1690 & 11150 \\
\hline & Basal stratified & Clearer ice & 4 & 8 & 66 & 26 & 96 \\
\hline
\end{tabular}

the white bubbly ice is identical to weathered rock-fall material around and on the glaciers (Gordon and others, 1978; Birnie, unpublished). It is mostly derived from the dominant rock type on this part of South Georgia, a fissile greywacke. This debris has undergone passive transport in the glaciers (Boulton, 1978) and has not been modified.

Debris in the basal sequences is quite different in form, size, and colour, although it is mostly derived from the same parent material. Individual clasts are more rounded, abraded, and striated. Unaffected by surface weathering, the material is grey in colour. The particle-size distribution reveals multi-modal peaks characteristic of subglacial crushing and abrasion (Drewry, 1986). Peaks in the gravel size reflect rock fragments, while peaks in the smaller size range indicate mineral grains.

This conclusion was confirmed by examining the grainsize of the two main component rocks in the area (Fig. 5c). The greywacke sample shows peaks at $0.4 \mathrm{~mm}$ and $4-6 \mu \mathrm{m}$, while the volcaniclastic sample shows peaks at $0.5 \mathrm{~mm}$ and $63 \mu \mathrm{m}$. Similar peaks can be picked out on curves for the Nordenskjöld Glacier debris bands. Here, the clay component in one sample is finer than the characteristic mineral grain-size and this is likely to be due to abrasion (Haldorsen, 1981). All these characteristics are convincing evidence that the debris in the basal ice sequences has undergone crushing and abrasion at the ice-rock interface.

The nature of the ice associated with the two types of debris is also distinctive. The white bubbly ice with intercalated layers of blue ice is widely accepted to be glacier ice unmodified by refreezing or by contact with the glacier bed (Lawson, 1979). On the other hand, clear ice with few or no bubbles and debris contained in or between crystal boundaries or in thin laminations is characteristic of basal freezing.

\section{D $/ \delta^{18} \mathrm{O}$ CHARACTERISTICS}

Co-isotopic analyses were undertaken to test the conclusions derived from the debris studies. In particular, it was hoped to differentiate ice originating by basal freezing from glacier ice which had not touched the bottom. Samples were taken from the basal ice sequence and white bubbly ice immediately above. In addition, samples were obtained from one basal sequence in Nordenskjöld Glacier to establish the nature of the relationship between $\delta D$ and ${ }^{18} \mathrm{O}$ in the basal ice. It is this relationship which can be used to establish the occurrence and amount of regelation (Jouzel and Souchez, 1982) as well as the characteristics of the parent water (Souchez and de Groote, 1985).

On Nordenskjöld Glacier, the samples were taken from debris bands, thinly laminated ice, and white bubbly glacier ice, as shown on Figure 4. On Lyell Glacier, four samples were taken from the basal series $200 \mathrm{~m}$ east of the sea (L3, $\mathrm{L} 4, \mathrm{~L} 5$, and $\mathrm{L} 6$ sampled $6 \mathrm{~m}, 3 \mathrm{~m}, 1 \mathrm{~m}$, and $0.5 \mathrm{~m}$ above the base, respectively). Of these, only $\mathrm{L} 6$ came from a debris layer ( $30 \%$ by weight). Two samples (L1 and L2) came from white bubbly ice $1.5 \mathrm{~m}$ and $1 \mathrm{~m}$ above the basal ice series, respectively. On Hodges Glacier, three samples came from the basal ice series, five from successive white bubbly ice layers between the snout and the firn line, and one from old snow just above the firn line (Fig. 6).

The results from all three glaciers are shown in Figure 8. The $\delta D$ and $\delta^{18} \mathrm{O}$ values obtained are expressed in per mil versus SMOW (Standard Mean Ocean Water with $\mathrm{D} / \mathrm{H}$ and ${ }^{18} \mathrm{O} /{ }^{16} \mathrm{O}$ respectively equal to 155.76 and $2005.2 \mathrm{ppm}$ ). Precision of the measurements is $\pm 5 \%$ in $\delta \mathrm{D}$ and $\pm 0.1 \%$ in $\delta^{18} \mathrm{O}$. For convenience, they are drawn with $\delta^{18} \mathrm{O}$ on the

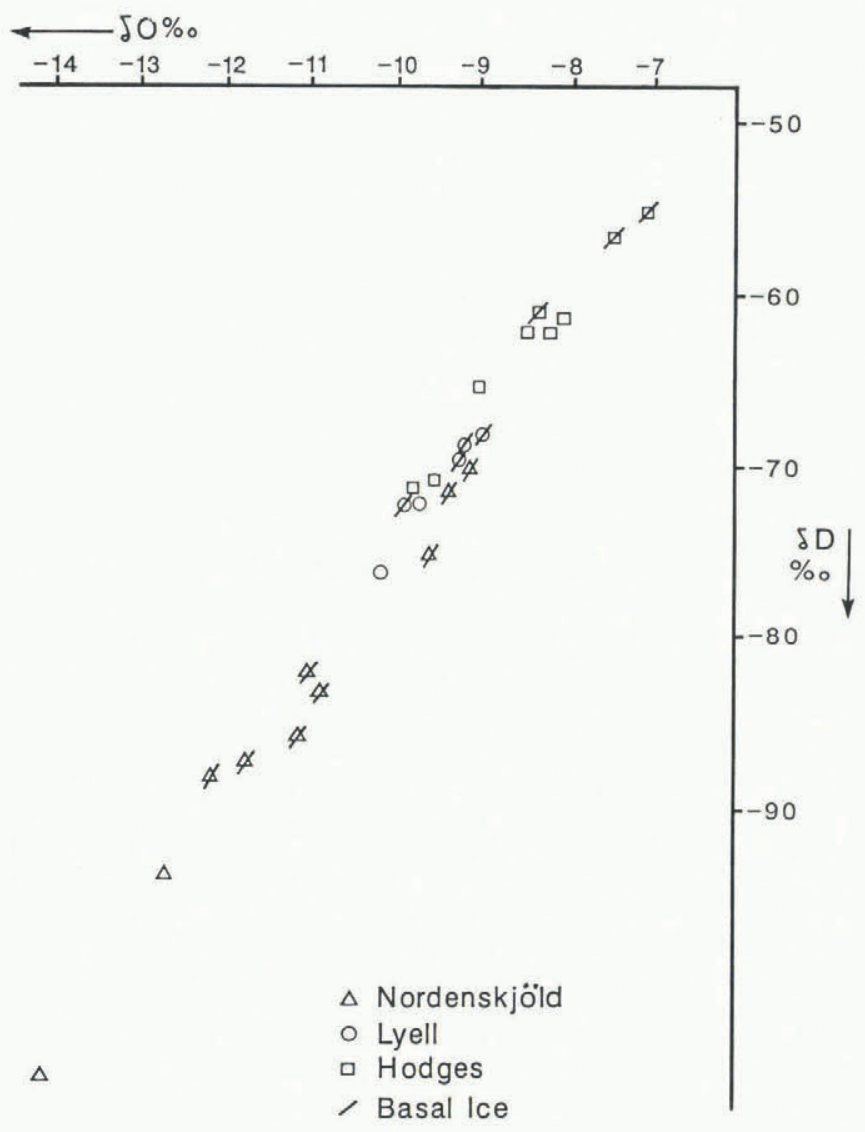

Fig. 8. $\delta D / \delta^{18} O$ values obtained from the three South Georgia glaciers. They are grouped by glacier and by ice type.

abscissa and $6 \mathrm{D}$ on the ordinate, following Jouzel and Souchez (1982). It is interesting to observe that the values for each glacier cluster on different parts of the diagram. This can be explained in terms of the different altitudinal range of each glacier basin and is to be expected. Hodges Glacier is at the lowest altitude and its $6 \mathrm{D} / \delta^{18} \mathrm{O}$ values are closest to SMOW. As the altitude of a basin increases, 
snowfall becomes increasingly negative. Nordenskjöld Glacier, which backs into mountains over $2000 \mathrm{~m}$ high, has values similar to those of Glacier de Tsanfleuron in the European Alps (Jouzel and Souchez, 1982). Lyell Glacier, at an intermediate altitude, has values intermediate between Hodges Glacier and Nordenskjöld Glacier.

The contrast between the $\delta \mathrm{D} / \delta^{18} \mathrm{O}$ characteristics of the basal ice and pure glacier ice of Nordenskjöld Glacier is shown in Figure 9. Samples N1 and N12 are white bubbly ice and, as expected, the $\delta \mathrm{D} / \delta^{18} \mathrm{O}$ relationship of these

\section{Nordenskjöld Glacier}

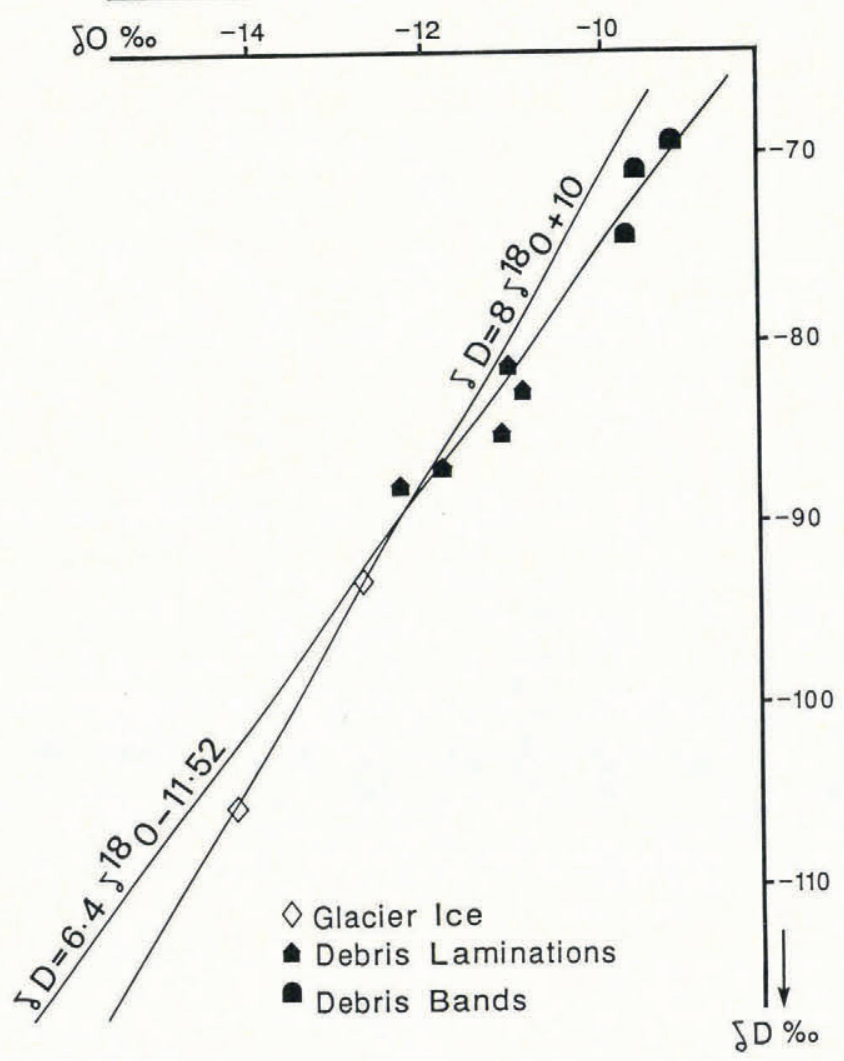

Fig. 9. The regression line drawn through $\delta D / \delta^{18} O$ values for the debris-bearing ice, Nordenskjöld Glacier (correlation coefficient $=0.98$ ) compared to a precipitation slope of 8 . The slope of 6.4 differs from the precipitation slope of pure glacier ice and demonstrates it has undergone refreezing.

samples is aligned along a slope of 8 , a direct relationship related to isotopic fractionation of water occurring during condensation or sublimation (Dansgaard, 1964). The remaining samples all involve ice from the basal series and they lie along a line with a slope calculated by linear regression to be 6.4. This is significantly different from the precipitation slope and reflects fractionation during refreezing. This value is in the range of theoretical predictions which would be expected from the freezing of parent water derived from pure Nordenskjöld Glacier ice. Thus, it seems reasonable to accept the isotopic values in South Georgia as convincing evidence that the debris-bearing ice has accreted by freezing-on.

It is interesting that the absolute values of the three debris-band samples are less negative than those of the rest of the basal ice. This might indicate that the debris bands represent an early stage in the freezing of the parent water and the laminated ice a later stage of freezing from the same reservoir. The total range of the refrozen ice samples above the level of the least negative white bubbly ice samples is more than $3 \%$ in $\delta^{18} \mathrm{O}$. This suggests that more than one cycle of melting and freezing may have occurred, since $3 \%$ is the maximum enrichment from the parent water than can occur during a single event.
The Hodges Glacier values are too few to calculate reliable slopes. However, Figure 8 shows that the basal ice samples are isotopically heavier than those of the pure glacier ice. This effect is characteristic of regelation ice formed by partial refreezing of a reservoir derived from a glacial parent water (Jouzel and Souchez, 1982) and agrees with the stratigraphical and debris evidence. The isotopic values of the Lyell Glacier samples are again too few in number to calculate reliable slopes. Nonetheless, it can be seen from Figure 8 that the pure glacier-ice samples lie close to the precipitation slope of 8 and that the four basal ice samples would fit a shallower slope; also the basal ice samples are isotopically heavier. Again, the relationships agree with an origin by refreezing and support the stratigraphical and sedimentological evidence.

\section{THE ORIGIN OF BASAL ICE SEQUENCES}

Both the debris and isotopic analyses confirm the subglacial origin of the basal ice sequences and point to accretion by freezing-on. It remains to discuss why the thicknesses and stratigraphical characteristics of the sequences vary from glacier to glacier. The $1.3 \mathrm{~m}$ basal ice layer beneath Hodges Glacier with discontinuous lenses of debris is likely to relate to processes of regelation associated with the roughness of the glacier bed. For example, a bedrock bump of $1.3 \mathrm{~m}$ amplitude with no basal ice layer above it but with basal ice streaming round it lies immediately up-glacier of the sampling site. The discontinuous nature of the layer and the entrained debris point to a discontinuous process of refreezing such as would be associated with flow over and round bumps. The overall layer is apparently not being thickened by compressive flow near the snout, perhaps because the glacier has been in retreat since the $1960 \mathrm{~s}$ and terminates as a feather edge. The thick Nordenskjöld Glacier section represents the opposite extreme. Here, strong compressive flow is indicated by folds visible in marginal crevasses and by shear discontinuities (Fig. 4). Presumably, the debris sequence has been thickened considerably by such processes. Compressive flow is favoured by the position of the site at a pinning point beside a glacier whose snout is afloat and calving rapidly. Also, seasonal freezing of the landward margin may favour compressive flow.

The detailed characteristics of the debris throw some light on subglacial processes. Debris in the basal sequences of all three glaciers reflects the effects of crushing and abrasion, with clasts, rock fragments, mineral grains, and a fine clay/silt fraction present. There is an interesting contrast between the longer Nordenskjöld Glacier and shorter Hodges Glacier. Debris beneath the shorter glacier has presumably experienced less transport at the glacier base and it is notable that it contains proportionately more rock fragments, less silt/clay fraction, and more angular clasts than that of the longer Nordenskjöld Glacier.

The varied stratigraphy of the incorporated basal debris reflects different processes of entrainment. It is likely that the debris exposed at the snout of Nordenskjöld Glacier represents the wholesale freezing-on of the glacier bed, as in the case of the compact debris-dominant layers, or the periodic freezing-on of the bed as in cases of debris bands separated by thin ice layers. Debris bands which lack fines (such as N4; Fig. 5a) could represent the freezing-on of a part of the bed where melt water is flushing out the fine material. The laminated ice with millimetre-thick layers of debris is difficult to explain. One can suggest that the $1-2 \mathrm{~cm}$ thick "clear-ice" zones freeze on with small amounts of debris being incorporated within and between crystals. The problem is to explain the extensive millimetre-thick debris layers. Perhaps these represent the freezing-on of a thin subglacial film of water which is heavily charged with debris. In support of such a notion is the striking lack of debris coarser than $4 \mathrm{~mm}$ in the laminated ice samples (Fig. 5a). Perhaps coarser material is simply too big to pass along the basal water layer and is thus not available for freezing-on. The apparent continuity of thin debris layers is also a problem. Unlike the case of Hodges Glacier, the continuity suggests a process operating over many square metres of the glacier bed. In this context, the role of tidal 
flexure of the glacier could be important in that the rise and fall of the tide will modify basal pressures in the immediately adjacent grounded part of the glacier and allow instantaneous freezing of a subglacial water film over a relatively wide area.

\section{CONCLUSIONS}

1. The debris and co-isotopic characteristics of basal ice sequences in three South Georgia glaciers are best explained by freezing-on at the glacier base.

2. The basal ice sequences may be thickened by folding and shearing associated with compressive ice flow at the ice margin.

3. The basal debris in the sequences reflects processes of crushing and abrasion. The former process results in a characteristic multi-modal size distribution of the fraction smaller than $16 \mathrm{~mm}$, while the latter process produces claysized material. These characteristics are most clearly developed in the longer glaciers.

4. $\delta \mathrm{D} / \delta^{18} \mathrm{O}$ ratios of glacier ice in South Georgia demonstrate an altitudinal effect between glaciers.

\section{ACKNOWLEDGEMENTS}

We are pleased to acknowledge the support of the U.K Natural Environment Research Council (grant GR3/5199) for a field visit in 1985. We are grateful to the Royal Navy and especially HMS Endurance for travel to and within the island, the British Antarctic Survey for logistical help, R.A. Souchez and J. Jouzel for the co-isotopic analyses, and $\mathrm{M}$.
Lamb for the mechanical analysis. P.G.K. and J.C.G. were both funded by U.K. Natural Environment Research Council studentships at the time they were involved in the work.

\section{REFERENCES}

Birnie, R.V. Unpublished. Rock debris transport and deposition by glaciers in South Georgia. [Ph.D. thesis, University of Aberdeen, 1978.]

Boulton, G.S. 1978. Boulder shapes and grain size distributions of debris as indicators of transport paths through a glacier and till genesis. Sedimentology, Vol, 25, p. 773-99.

Dansgaard, W. 1964. Stable isotopes in precipitation. Tellus, Vol. 16, No. 4, p. 436-68.

Drewry, D. 1986. Glacial geologic processes. London, Edward Arnold.

Gordon, J.E., and others. 1978. A major rockfall and debris slide on the Lyell Glacier, South Georgia, by J.E. Gordon, R.V. Birnie, and R. Timmis. Arctic and Alpine Research, Vol. 10, No. 1, p. 49-60.

Haldorsen, S. 1981. Grain-size distribution of subglacial till and its relation to glacial crushing and abrasion. Boreas, Vol. 10, No. 1, p. 91-105.

Jouzel, J., and Souchez, R.A. 1982. Melting-refreezing at the glacier sole and the isotopic composition of the ice. Journal of Glaciology, Vol. 28, No. 98, p. 35-42.

Lawson, D.E. 1979. Sedimentological analysis of the western terminus region of the Matanuska Glacier, Alaska. CRREL Report 79-9.

Souchez, R.A., and Groote, J.M. de. 1985. $\delta \mathrm{D}-\delta^{18} \mathrm{O}$ relationships in ice formed by subglacial ireezing: paleoclimatic implications. Journal of Glaciology, Vol. 31, No. 109 , p. 229-32. 